\title{
Manasseh, King of Judah, in Early rabbinic Literature: An Erudite, Unfettered, and Creative Biblical Critic
}

Hananel Mack

King Manasseh of Judah is one of three kings and four commoners who have no share in the world to come. The other two kings are Jeroboam and Ahab, kings of Israel, who, according to the first mishnah in perek Helek (tractate Sanhedrin 10:1), ${ }^{1}$ join the ranks of Balaam, Doeg the Edomite, Ahitophel, and Gehazi, the servant of the prophet Elisha.

The primary sources of information about Manasseh in the Bible are concentrated in two comparable, though not identical chapters. 2 Kings 21 describes Manasseh's actions in the familiar biblical language of censure. "He did what was displeasing to the Lord, following the abhorrent practices of the nations" (21:2). However, this chapter also uses particularly harsh language, uniquely applied to the deeds of this king: Manasseh rebuilt the altars to Baal and Asherah "as King Ahab of Israel had done" (3), "bowed down to all the host of heaven" (3), "consigned his son to the fire; he practiced soothsaying and divination, and consulted ghosts and familiar spirits" (6), and, in general, "did much that was displeasing to the Lord, to vex Him" (6). He corrupted his people: "Manasseh led them astray to do greater evil than the nations that the Lord had destroyed before the Israelites" (9), and shed blood: "Moreover, Manasseh put so many innocent persons to death that he filled Jerusalem [with blood] from end to end-besides the sin he committed in causing Judah to do what was displeasing to the Lord" (16). In Chronicles 2:33 this description is 
repeated without significant changes, although verses 11-19 introduce a new, previously unfamiliar aspect of Manasseh's story that will be discussed later.

The "sin of Manasseh" is mentioned in several additional biblical sources. Near the end of 2 Kings, ${ }^{2}$ the sins of Manasseh are presented as the major catalyst for the destruction of the First Temple and its accompanying horrors: "However, the Lord did not turn away from His awesome wrath which had blazed up against Judah because of all the things Manasseh did to vex Him” (2 Kings 23:26). "All this befell Judah at the command of the Lord, who banished [them] from His presence because of all the sins that Manasseh had committed" (24:3). This same idea is also expressed in the book of Jeremiah: "I will make them a horror to all the kingdoms of the earth, on account of King Manasseh son of Hezekiah of Judah, and of what he did in Jerusalem" (Jer. 15:4).

Fifty-four years elapsed between Manasseh's death and the destruction of the Temple, and to this must be added the final years of his rule when he distanced himself to a large degree from his earlier policies, as will be discussed below. For most of the period after Manasseh's reign, the righteous King Josiah ruled in Jerusalem. He made a wholehearted attempt to return Judah to the right path and to correct the Manasseh's wrongdoing: "And the altars made by Manasseh in the two courts of the House of the Lord. He removed them from there" (2 Kings 23:12). Nonetheless, the sin of Manasseh the son of Hezekiah sealed the fate of Jerusalem, and ensured that Manasseh be numbered among the three kings that have no place in the world to come.

Josephus Flavius presents a similar picture, but in one particular aspect his depiction is even more severe than that presented in the Bible: "For in his contempt for God, he hastened to kill all those who were just among the Hebrews; he did not even have mercy on the prophets, but butchered some of them every day so that Hierosolyma ran with blood." 3 Still, it must be emphasized that the biblical sources identify idolatry and its systematic proliferation, not bloodshed, as Manasseh's quintessential sin.

As I have pointed out, Chronicles adds an additional element to Manasseh's story, an element that is repeated by Josephus: Manasseh's captivity and torture at the hands of the king of Assyria. ${ }^{4}$ As a result, "in his distress, he entreated the Lord his God and humbled himself greatly before the God of his fathers. He prayed to Him, and He granted his prayer, heard his plea, and returned him to Jerusalem to his kingdom. Then Manasseh knew that the Lord alone was God” (2 Chron. 33:12-13). This additional information led Rabbi Judah to disagree with the first opinion stated in the mishnah and declare that "Manasseh has a portion in the world to come." The other sages responded: "He was restored to 
his kingdom but not to the world to come." This description of how Manasseh's deeds, punishment, and prayer led him to believe in God corresponds to the basic and familiar concept that Manasseh's sins were first and foremost idolatry and not murder and bloodshed. ${ }^{6}$

It is possible to understand the disagreement between the first opinion in the mishnah, Rabbi Judah, and the other sages as a debate over the meaning and value of the information Chronicles provides supplementing the narrative in Kings. ${ }^{7}$ In any case, the controversy surrounds the Biblical narrative. Rabbi Akiva's discussion in Sifrei Devarim ${ }^{8}$ about Manasseh and the suffering that led him to repent, and its reworking in the Babylonian Talmud are based, albeit indirectly, on the Biblical text. ${ }^{9}$

Rabbi Akiva presents Manasseh as an eminent rabbi who went astray, and whose knowledge of Torah was not enough to lead him back to repentance. Rabbi Akiva's conclusion that only suffering returned Manasseh to the path of righteousness is not a fanciful interpretation, but almost exactly the plain meaning of the text in Chronicles. The opinions of the Palestinian amoraim in the Pesikta de-Rav Kahana on haftarat Shabbat Shuva, ${ }^{10}$ and the parallel discussion of Manasseh in the Jerusalem Talmud, ${ }^{11}$ expand extensively on the narrative in Chronicles. They do not, however, deviate from the spirit of the biblical text regarding the nature of Manasseh's sin. In the Pesikta, Manasseh appears in the company of other sinners who mended their ways to a greater or lesser degree, and whose repentance was at least partially accepted. This too is based directly on the biblical text or its interpretation. ${ }^{12}$ Rabbi Yohanan's opinion, found in the Babylonian Talmud, that strengthens the connection between Jeroboam, Ahab, and Manasseh is also part of this trend. ${ }^{13}$

However, despite what is stated explicitly in the books of Kings, Jeremiah, and Chronicles, and in the rabbinic literature cited here, there are other tannaitic and amoraic sources that emphasize another side of Manasseh's personality and the nature of his crimes. These independent amoraic sources are the products of the interpretations of Babylonian amoraim.

\section{2}

About ten years ago, Aharon Shemesh published an article connecting the schism between the Sadducees and the Pharisees to a baraita that relates a commentary in the name of Manasseh, King of Judah. ${ }^{14}$ In the first part of the article, Shemesh cites a halakhic/legal controversy between the Boethusians and the Pharisees regarding a daughter's inheritance-one of the classic subjects of debate between the Pharisees and the Sadducees at the end of the 
Second Temple period. The scholion (commentary) on Megilat Ta'anit relates a debate between Rabbi Yohanan ben Zakkai and "an elder who gossiped about him" and made false accusations against him. Rabbi Yohanan ben Zakkai quoted the following verse to him (or, in reference to him): "That was the Anah who discovered the hot springs in the wilderness while pasturing the asses of his father Zibeon" (Gen. 36:24). The controversy continued and, in the end, the Pharisees defeated the Sadducees "and that day was made a holiday." 15

While Rabbi Yohanan's words appear to be a meaningless insult, Shemesh argues that they should be understood differently. The polemical nature of this source is indisputable. Shemesh explains that "this baraita is one of three baraitot cited in the scholion ... both they and their counterparts in an identical literary framework within the Talmud ${ }^{16}$ are clearly polemical." ${ }^{17}$ I will not elaborate here on the debate concerning a daughter's inheritance nor on the exegetical methods used by the Pharisees, led by Rabbi Yohanan, in their efforts to make a ruling on the subject. However, it is important to point out that the Pharisaic/rabbinic interpretation is not consistent with a simple reading of Genesis 36:20-30. The simple meaning of the verses is that there were two people by the name of Anah in the family of Seir the Horite, while Rabbi Yohanan ben Zakkai interprets the verses to mean that both "Anah"s refer to one and the same person. On this basis, genealogical conclusions are derived regarding the two women, Oholibamah and Timna, mentioned in the verses. According to Shemesh, each of these conflicting conclusions corresponds to one of the competing halakhic positions; the interpretation furthest from the simple meaning of the text corresponds to the opinion of the Pharisees. The words "and Lotan's sister was Timna" (22), therefore, have a special meaning. Shemesh argues that the identity of Timna is the basis of the Sadducee position regarding female inheritance.

Thus, in a tannaitic derashah (homiletic interpretation) whose source is the midrash Sifrei on Numbers, Manasseh, King of Judah is mentioned in the context of the discussion of Timna. This derashah is based on Numbers 15:3031: "But the person ... who acts defiantly reviles the Lord; that person shall be cut off from among his people. Because he has spurned the word of the Lord and violated His commandment."

The midrash reads:

"Who acts defiantly" - this is one who interprets the Torah inappropriately, like Manasseh son of Hezekiah. "Reviles the Lord” refers to one who makes blasphemous commentaries saying: "Did He not have anything 
more important to say than 'Reuben came upon' (Gen. 30:14), or 'and Lotan's sister was Timna?” (36:22). To this behavior, tradition ascribes the verse: "You are busy maligning your brother" (Ps. 50:20) $1{ }^{18}$

This derashah also appears with minor changes as a baraita, under the heading "The Rabbis Have Taught," in the Babylonian Talmud (tractate Sanhedrin 99b). ${ }^{19}$

A cursory reading of these sources reveals that Manasseh is presented as an amateur exegete who derides Moses and his Torah and claims that it contains a list of meaningless irrelevancies. Shemesh does not agree with this reading. He maintains that Manasseh is described in these sources as an exegete, and suggests the possibility that the comments cited in his name are the "opening words of commentaries, real interpretations." ${ }^{20}$ According to this approach, behind the derision directed toward the apparently meaningless words "and Lotan's sister was Timna" lies the Sadducee interpretation mentioned above. Shemesh attempts to reconstruct the remainder of this Sadducee exegesis ascribed to Manasseh. He then analyzes the meanings of the expressions unique to the verses cited by Manasseh and to the baraita cited in the Sifrei, and the use made of these biblical expressions by the Pharisees' opponents in order to refute their rivals. Shemesh concludes that the midrash in the Sifrei about Manasseh was the Pharisee response to this Sadducee attack. Manasseh, King of Judah is thus presented in the Sifrei and in the Talmud as an educated and knowledgeable Sadducee commentator: a heretic who authors blasphemous commentaries and inappropriate interpretations. One could go even further and say that these sources present Manasseh as an ancient biblical critic, unbeholden to rabbinic opinions, commentaries, exegetical methodology, or halakhic authority, who favored the explicit, peshat meaning over tradition and rabbinic midrash.

Manasseh's derisive attitude toward the verse beginning "Reuben came upon" (Gen. 30:14) and the story of the mandrakes is compatible with this theory. ${ }^{21}$ The biblical story of the mandrakes and the birth of Issachar confuses all readers. Ascribing to Manasseh the derisive question of why Moses bothered to include this episode in the Torah at all intensifies this uneasiness, and emphasizes the moral and literary difficulties inherent in the story. Moreover, Manasseh's choice of the tribe of Issachar specifically as his object of ridicule is polemical in its own right, as I will explain below.

Ridicule of the tribe of Issachar and the story of its forefather's birth is also expressed clearly in another source: the text known as Tzavaot Bnei Yaakov or Tzvaot ha-Shevatim [The wills of the sons of Jacob/the tribes]. This work 
is an anonymous composition from the Second Temple era whose dating, editor, and literary sources are unknown. This is not the appropriate forum for an extensive discussion of either the nature of these "wills," or the question of whether some or all of the sages were familiar with the work. It is clear, however, that if the sages were aware of these writings, they were not pleased with them. The texts include harsh criticisms of several figures in Genesis, including the Patriarchs, and many passages reveal profound Hellenistic influences. Other sections indicate Christian spiritual influences, although it can be surmised that these passages were added at a later date.

The story of the mandrakes that Reuben brought to his mother is told at length in the first part of "The Will of Issachar." On his death bed, Issachar tells his offspring the story of the mandrakes that led to his conception and birth. In a crass and popular vein, the text recounts the continued quarreling and animosity between Rachel and Leah, beginning with the unforgettable events of the first wedding night and bitter morning after. Now, Rachel grabs the mandrakes from her nephew and refuses to give them back. Leah declares: "Jacob is mine because I am his first wife!" Rachel answers: "You are not his wife! You were given to him in deceit. My father deceived me and sent me away that night . . but I will sell you one night with Jacob for these mandrakes."

In comparison, the Book of Jubilees, an apocryphal work, does not mention the story of the mandrakes. The author of the Tzvaot ha-Shevatim was far from deferent to the important figures of Genesis. He thought and wrote in a manner fundamentally different from that of the sages, and lacked their respect for the Bible and its heroes. Many rabbinic commentaries and midrashim criticize biblical figures, but not in such cheap and crude manner.

The two commentaries attributed to Manasseh complement each other in another way. His halakhic commentary on Timna favors a woman, both halakhically and financially. His aggadic commentary about the mandrakes, however, diminishes the stature of biblical women. Neither found favor with the sages because they emanated from a negative and inimical source.

Manasseh's midrash about the mandrakes and "The Will of Issachar," both reveal contempt for the tribe of Issachar. A well-known tradition from the tannaitic period regards Issachar as a tribe that studies Torah. A midrash in the Sifrei comments on the verse "And of Zebulun he said: Rejoice, O Zebulun, on your journeys, and Issachar, in your tents" (Deut. 33:18): “This teaches us that the tribe of Issachar excels in Torah study, as it is written: 'Of the Issacharites, men who knew how to interpret the signs of the times" (1Chron. 12:33). This interpretation reappears in various guises throughout rabbinic literature, and 
inspired the idea, developed in the time of the amoraim, of the partnership between the Torah scholars of Issachar and the tribe of Zebulin that supported them. A midrash in the Sifrei on Numbers refers to the tribe of Issachar as Torah scholars: Netanel son of Zoar, the prince of Issachar, suggested to his friends to bring the princely sacrifices to the dedication of the Tabernacle. Therefore, "he merited that wisdom be given to [from] his tribe, as it is written 'of the Issacharites,' and the Bible also praises the tribe's courts of law in Egypt."22 There is no doubt that, in the opinion of these commentators, the Torah scholarship of the tribe of Issachar is thoroughly Pharisaic and identical with that of the tannaim. Ridicule of Issachar's origins implies contempt for his Torah study, and for that of the Pharisees as a group.

The complete verse from Chronicles about Issachar reads: "Of the Issacharites, men who knew how to interpret the signs of the times, to determine how Israel should act; their chiefs were 200, and all their kinsmen followed them" (1 Chron. 12:33). The phrase "to interpret the signs of the times" is understood in several places to indicate thorough knowledge of the calendar. This verse is therefore understood to mean that the members of the tribe were tasked with reckoning the calendar in all its detail and instructing the People of Israel according to their calculations and their traditions. Although this interpretation first appears in the amoraic period, it is possible that it existed earlier, and, in any case, is not far from the simple meaning of the verses. Questions relating to the calendar, such as adding a leap month, testimony about the appearance of the new moon, the timing of the holidays, and related matters, were central issues in the controversy between the Pharisees, Sadducees, and Boethusians, and are reflected clearly in both rabbinic and sectarian literature. It would appear that contempt for the tribe of Issachar and its inferior origin is connected to the heated and prolonged controversy about the calendar and the festivals. This contempt is also reminiscent of Sadducee culture, which was typically associated with the aristocracy and disdained the lower socioeconomic classes and those of low or questionable birth.

"The Will of Issachar" and the baraita in Sifrei Ba-Midbar both convey the same message: Manasseh the son of Hezekiah was an outspoken and dangerous exegete. Taken together, the two commentaries ascribed to Manasseh reveal him to be a biblical critic who adheres to the simple meaning of the text (peshat) and who did not accept the exegetical authority of the sages regarding either halakhah or aggadah. The figure of Manasseh that emerges from the Sifrei on Numbers and the parallel Talmudic passages is a prototype of the 
critic, educated and erudite but also crude and vulgar, who is dismissive of the sages' tradition of reading the biblical text with careful attention to its halakhic and aggadic implications.

\section{3}

The mishnah in tractate Yevamot cites Ben Azzai's statement that he found a secret scroll in Jerusalem. ${ }^{23}$ A baraita in the Talmud elaborates on this statement and relates the three items that were found written in this scroll. The third is the terse statement that "Manasseh killed Isaiah," referring to Isaiah the prophet. From the point of view of chronology, this would appear unlikely, though not impossible. ${ }^{24}$ It would mean that Manasseh killed a venerable person, no less than a prophet, ${ }^{25}$ and a very elderly man. ${ }^{26}$ Though the concept that Manasseh killed Isaiah is not grounded in the biblical text, it is essentially compatible with the verse cited above: "Moreover, Manasseh put so many innocent persons to death that he filled Jerusalem [with blood] from end to end" ( 2 Kings 21:16). This idea is also consistent with Josephus Flavius's description of Manasseh as a killer of many prophets, and with the descriptions found in the apocryphal work Aliyat Yishayahu [The rise of Isaiah] and later Christian traditions based upon it. In the Babylonian Talmud, the amora Raba develops his discussion of the execution of Isaiah at the hands of Manasseh into a kind of play, centered around a profound legal discussion between the prophet and the king that precedes the execution. ${ }^{27}$ Raba declares that "he put him on trial and then killed him"; in other words, the king executed the prophet only after trying him as a criminal.

It would appear that, although obscure traditions may have preceded his discussion, it was Raba who first portrayed an open trial in which Manasseh the son of Hezekiah accused Isaiah the son of Amotz of a series of sins of heresy and rejecting the words of the Torah as written by Moses.

Here there are no blasphemous commentaries such as those found in the Sifrei and the baraita, but rather three substantial claims, all of which are based on a comparison between the Torah and the book of Isaiah.

Manasseh's first accusation is: "Your teacher Moses said: 'For man may not see Me and live' (Exod. 33:20), and yet you said: 'I beheld my Lord seated on a high and lofty throne' (Isa. 6:1)." His second claim is: "Your teacher Moses said: 'For what great nation is there that has a god so close at hand as is the Lord our God whenever we call upon Him?' (Deut. 4:7), and you said: 'Seek the Lord while He can be found, call to Him while He is near' (Isa. 55:6)." His third claim is: "Your teacher Moses said: 'I will let you enjoy the full count of 
your days' (Exod. 23:26), but you said: 'And I will add fifteen years to your life' (2 Kings 20:6)." 28

These are serious arguments. The narrator of the Talmud does not elaborate or explain the contradictions. He provocatively leaves the questions open, which gives the reader the impression that there is real truth to Manasseh's accusations. Manasseh son of Hezekiah, the king of Judah, is not merely a crass and ignorant murderer and idolater, but a man well-versed in the Torah and Prophets, who reads these texts carefully, compares them, and draws conclusions. In other words, Manasseh is an intelligent and knowledgeable Bible critic. He debates the greatest Jewish spiritual figure of his generation, and his arguments are not easily refuted.

But Manasseh is not merely a biblical critic. He is also the person responsible for keeping the peace of the nation. In his role as king of Judah, he fulfills his religious duties and tries a man who dared to challenge the Torah of Moses. Isaiah's fame as a prophet and his advanced years did not merely fail to save him from death; on the contrary, they increased the severity of his sin and placed him in the category of a "rebellious elder" deserving of death. The tables have turned; Isaiah is guilty of a mortal sin and Manasseh zealously upholds the word of God, almost like Elijah the prophet in his day.

The "political" aspect of this story deviates from the framework of this article, because discussions about biblical commentary, beliefs and opinions, and doubts and certainties usually take place between a traditional believer and a sober critic and remain abstract. Usually, these kinds of discussions do not take place between a ruler and his subject, and generally speaking do not evolve into a legal or political confrontation that threatens the life of one of the disputants. Nonetheless, Raba's presentation of Manasseh's arguments sounds like debates between Bible critics and traditional, believing, Torah scholars, without the political backdrop of this talmudic story.

According to the talmudic account, Isaiah chooses not to respond to these difficult questions, and remains silent because, as he says: "I know that he will not accept any answers I give him." In other words, the scholar has convincing answers but he knows that the erudite critic will not accept them. Moreover, the conscientious scholar says to himself: "If I tell him, I will turn him into a willful sinner." On these grounds, he decides to leave his rival guilty of nothing more serious than unintentional misconduct. The prophet knows that his fate is sealed, but in the goodness of his heart he allows Manasseh to retain his self-image as one who follows halakhah and lawfully executed a heretic. Even in a nonpolitical debate about the Bible with no serious repercussions, a 
Torah scholar, aware that his answers will not convince the critic, might choose to remain silent in order to allow the critic to remain an unintentional sinner, righteous in his own eyes.

In the talmudic account, Isaiah decides to run for his life. Using the power of the Holy Name, he causes a cedar tree to swallow him and hides inside. However, the king discovers his whereabouts and saws down the tree. When the saw reaches his mouth the fugitive dies. Does Manasseh here revert to his original biblical persona of blood-thirsty murderer? Or, does he play the role of a ruler who is ridding the world of a heretic pretending to be God's prophet? This question requires clarification in its own right, and is beyond the scope of this paper. I will, however, point out that the talmudic narrator can explain why the prophet died precisely when the saw reached his mouth. This was punishment for Isaiah's words: "I live among a people of unclean lips" (Isa. 6:5). The prophet's real mortal sin was the description of his audience as "a people of unclean lips."29

Up to this point, the critic's questions have been left unanswered. However, the narrator is not willing to let the matter rest. He presents detailed answers to the three questions that the wicked king asked God's prophet. I will not discuss the answers themselves, other than to point out that they answer key theological questions: What is the difference between the prophecy of Moses, who saw through "clear glass" (or "a mirror"), and the other prophets (including Isaiah)? What is the significance of Moses' special status and his unique knowledge of God? Is there a difference between the religious status of individual and communal repentance? Are there limitations, temporal or otherwise, on an individual's ability to repent? What qualities are unique to Rosh Hashanah, Yom Kippur, and the intermediate days of repentance? Is the length of a person's life allotted to him from the day of his birth or determined (also) by his way of life? Does a prophecy's fulfillment depend on the behavior of the one who prophesized? 30

The discussion of these subjects emanates from the critic-king's questions, left unanswered by the beleaguered prophet. The talmudic narrator, not wanting to leave the questions open, answers them himself. The narrator thereby teaches us a very important lesson: even if the critic himself is an unworthy person, it is incumbent upon us nonetheless to give serious consideration to his opinions and to attempt to answer his questions. This can be seen as the fulfillment of the sound advice given by the author of Proverbs: "Answer a dullard in accord with his folly, else he will think himself wise" (26:5). Moreover, it fulfills Maimonides' adage: "Accept the truth from whatever source it 
proceeds" 31 _ even if the speaker is a critic, a skeptic, a heretic, or a wicked king who has no portion in the world to come.

\section{4}

In conclusion, I would like to discuss the beautiful story of Rav Ashi's dream of his conversation with Manasseh, the king of Judah. ${ }^{32}$ According to the story, the amora Rav Ashi concluded a daily public lecture by citing the Mishnah about the three kings who do not merit the world to come. He ended the lesson with the words: "Tomorrow we will begin with our friends." Manasseh came to him in a dream and confronted him angrily. "Do you call us your friends and the friends of your father?" Manasseh asked. Rav Ashi did not respond. Manasseh attacked him further by asking the amora a halakhic question in the talmudic style: "After saying the blessing on the bread, what part of the bread should one break first?" Rav Ashi answered honestly: "I don't know." Manasseh continued to badger him. "You don't even know where to break the bread, and yet you call us friends?" Rav Ashi, astounded, responded: "Teach me, and tomorrow I will teach others your opinion during my public lecture to the scholars.” Manasseh responded: "One should break the bread in the place where the top of the bread is crusted."33

Rav Ashi did not respond directly, and it can be assumed that he fell temporarily silent because he perceived that he had been vanquished. Manasseh's justifiable anger and his words perplexed the dreaming Rav Ashi, who then asked: "If you and your royal friends are so wise, why did you worship idols?" To this Manasseh replied: "If you had been there, you would have held on to the hems of the robe [of the idol?] and run after it." 34 Manasseh's intention is that Rav Ashi would have been more devoted to idolatry than he was, or, to put it another way: "You are incapable of understanding how strong and deep the temptation to worship idols was in our day." Here Manasseh opened possibilities for further discussions of religion, philosophy, and psychology.

Rav Ashi, like the tannaim Rabbi Akiva and the author of the midrash in the Sifrei, as well as the Babylonian amora Raba and the talmudic narrator in tractate Yevamot, saw Manasseh as a Torah scholar. Here, however, in contrast to these other sources, Manasseh is depicted specifically as proficient in the Oral Law and halakhah. ${ }^{35}$ Manasseh the scholar, son of Hezekiah the saint, did not succeed in repenting for his sins. Manasseh the scholar of the Written Law bested Isaiah the prophet, and the Talmud was forced to provide answers to 
his astute and incisive questions. Manasseh the talmudic and halakhic scholar overwhelmed one of the greatest amoraim in his own field.

The Rabbis of the Mishnah and the Talmud constructed an image of Manasseh far removed from the Bible's coarse and vulgar mass murderer and idolater, the king whose deeds aroused the wrath of God that did not abate for years after his death and the destruction of the First Temple! Manasseh's new friends are not Jeroboam son of Nabat or Ahab son of Omri, the kings of Israel, but anonymous Torah scholars, similar to Elisha ben Abuyah and his ilk, who reject the authority of the sages and their followers. It is worth noting the similarity between this new Manasseh and the best of the biblical critics of the recent past: erudite, intelligent, learned, and well-versed in both Written and Oral Torah; sometimes generous in spirit and pleasant, and sometimes scathing and deprecating. Consider how impressed the sages were with their opponent, and how they struggled to respond to his blasphemous commentaries, his claims of contradictions between the Torah and the Prophets, and his complaint of unfair bias toward himself and his friends. Consider also how much Manasseh's biblical criticism contributed to the bold and incisive examination of questions fundamental to Jewish belief.

\section{Endnotes}

1. As it appears in most editions of the Mishnah, and in the Mishnah within the Jerusalem Talmud. However, in the Babylonian Talmud these words are part of the preceding mishnah.

2. The well-known baraita in tractate Bava Batra 14b ascribes the authorship of the book of Kings to Jeremiah and, in fact, at least in its final chapters, the book of Kings reflects the influence of Jeremiah and the book of Jeremiah. This influence is reflected in the blame placed upon Manasseh and his sins for the destruction of the First Temple in the book of Kings.

3. Josephus, Judean Antiquities, ed. and trans. Christopher T. Begg and Paul Spilsbury, vol. 5 of Josephus Flavius: Translation and Commentary, ed. Steve Mason (Leiden: Brill, 2005), 218.

4. "And led him off to Babylon" (2 Chron. 33:11). The names Assyria and Babylon are often interchangeable in biblical passages pertaining to the end of the First Temple period. Josephus also describes the capture of Manasseh by the king of Babylon.

5. Mishnah, tractate Sanhedrin 10:1.

6. The apocryphal work known as Tefilat Menashe [The prayer of Manasseh] neither adds nor detracts from our discussion, perhaps because there is no real connection between this text and the life, sin, and repentance of Manasseh as they are described in the Bible. The author of the Prayer put in the supplicant's mouth words of remorse for his grievous sins and a supplication asking God to forgive him for his misdeeds. Nowhere in these passages is there an explicit reference to Manasseh. The phrases "because I am in captivity" (9) or "do not cast me out of Your presence, while I am in the depths of the earth" (13) are not enough to connect the Prayer to Manasseh, the king of Judah. Other factors also disprove its pseudoepigraphic ascription to Manasseh. 
7. The question of the exact connection between the opinion cited as "they responded" and the first opinion requires further examination.

8. Sifrei Devarim, 32.

9. Babylonian Talmud, tractate Sanhedrin 101a-b.

10. Pesikta de-Rav Kahana, ed. Dov Mandelboim (New York: Jewish Theological Seminary of America, 1987), 2:364-365.

11. Jerusalem Talmud, tractate Sanhedrin 10:2, 28c.

12. Manasseh's colleagues in this passage are Cain; Ahab, the king of Israel; Joachin, the king of Judah; the people of Nineveh; and the people of Anatot.

13. Babylonian Talmud, tractate Sanhedrin 103a.

14. Aharon Shemesh, "Mah Gilah Menashe ben Hezekiah be-Torah? Al Sridei Halakhah ZadokitKitatit be-Sifrut Hazal" [What did Manasseh ben Hezekiah discover in the Torah? Remnants of Sadducee-sectarian halakhah in rabbinic literature], Meghillot 2 (2004): 91-103.

15. Megilat Ta'anit, ed. Vered Noam (Jerusalem: Yad Ben-Zvi, 2004), 223-225. The quoted passage is on 223.

16. The principal passage: tractate Bava Batra 115b-116a

17. Shemesh, "Mah Gilah," 98.

18. The passage opens with the words: "And to the wicked, God said: 'Who are you to recite My laws ... seeing that you spurn my discipline, and brush My words aside?" (Ps. 50:16-17).

19. The version of the derashah in the Horowitz-Rubin edition was influenced by the version in the Talmud.

20. Shemesh, "Mah Gilah," 100.

21. A few months before the publication of Aharon Shemesh's article, I discussed the sages' image of Manasseh, the king of Judah, in rabbinic literature with my students at Bar Ilan University. I showed them the tannaitic derashah and its amoraic development. I suggested to my students my interpretation (presented in this article) of the derisive derashah ascribed to Manasseh on the verse "Reuben came upon." However, I indicated that I did not have an explanation for Manasseh's interpretation of the verse "and Lotan's sister was Timna." In response, one of my students, Aviad Hollander, told us that he had heard a lecture by Professor Shemesh on this subject not long before. Aviad explained that Professor Shemesh had shared with his students his inability to find an explanation for Manasseh's apparent deprecation of the verse beginning "Reuben came upon"; Shemesh mentions this point in his article on p. 100. That very evening I called my friend Aharon Shemesh and explained my interpretation to him, and he informed me that his article on the subject was completed and would be published within a few weeks in Meghillot, a journal specializing in research on the Dead Sea scrolls and Second Temple literature. I quickly contacted the journal's editors, Professors Deborah Diamant and Moshe Bar-Asher, and asked them to publish in the same issue my interpretation of the second part of the derashah. I committed my ideas to writing, and thus the two articles were published one after the other in the same issue: Aharon Shemesh's "Mah Gilah Menashe ben Hezekiah be-Torah?" [What did Manasseh ben Hezekiah discover in the Torah?], and my "Mah od Gilah Menashe ben Hezkiah be-Torah?" [What else did Manasseh ben Hezekiah discover in the Torah?].

22. Sifrei Ba-Midbar 52:140.

23. Mishnah, Yevamot 4:13; Babylonian Talmud, tractate Yevamot 49a.

24. Isaiah prophesied in the time of the Judean kings Uzziah, Jotham, Ahaz, and Hezekiah (Isa. 1:1). It is generally accepted that chapter 6 of the book is the initiation prophecy of the prophet. If we understand the opening verse "in the year of the death of King Uzziah" according to its simple meaning, it appears that the prophet was, in fact, active for one year of 
Uzziah's reign, during the sixteen-year reigns of Jotham and Ahaz, and an unspecified period of time during the reign of Hezekiah (who reigned for twenty-nine years). Sennacherib's siege on Jerusalem began and ended in the fourteenth year of Hezekiah's reign (2 Kings 18:13; Isa. 36:1), and shortly afterward Hezekiah fell ill and recovered (2 Kings 20:1; Isa. $38: 1$ ). Isaiah was an active participant in all these events, and, thus, was active for forty-seven years all told. If we accept at face value the report that Manasseh murdered Isaiah, and assume that Manasseh did so after succeeding his father, it is necessary to add another fifteen years to the prophet's life and conclude that he was murdered at least sixty-two years after beginning his career. We must also assume that he began to prophesy as an adult (as opposed to Jeremiah who said of himself "for I am still a boy" [Jer. 1:6]), and, if so, at the time of his murder he was over eighty years old. A long life, but within the realm of possibility.

25. From several prophecies within the book of Isaiah, a picture emerges of a prophet connected to the people, addressing them in second person plural. See, e.g., Isa. 1.

26. In Dikdukei Ha-Te'amim, ascribed to Aharon Ben-Asher, the years of the prophecy of Isaiah are calculated from the beginning of the reign of Uzziah (who reigned for fifty-two years) until the first year of the reign of Manasseh, one hundred and fourteen years altogether. Dikdukei Hate'amim le-rabbi Aharon Ben-Asher, ed. S. Baer, H. L. Strack (Leipzig: Metzger Vetig, 1879), 57, § 70 .

27. Tractate Yevamot $49 \mathrm{~b}$.

28. This is the version that appears in the book of Kings. The corresponding verse in Isaiah 38:5 reads: "I hereby add fifteen years to your life."

29. This accusation continued to haunt Isaiah for generations. For example, in Iggeret Ha-Shemad (Ma'amar Al Kiddush Ha-Shem) [Epistle on martyrdom], Maimonides censures Isaiah for this verse, and raises similar criticism against Moses and Elijah.

30. This question is derived from Tosafot, tractate Yevamot 50a (s.v., teda).

31. The Eight Chapters of Maimonides of Ethics (Shemonah Perakim), ed. Joseph Gorfinkle (New York: Columbia University Press, 1912), 35-36.

32. Babylonian Talmud, tractate Sanhedrin 102b. Rav Ashi was one of the later amoraim, and is considered the editor of the Babylonian Talmud, or, at least, very involved in the editing process.

33. Rashi offers two explanations: The first is: "the place where the bread is crusted in the oven ... not in the middle." The second is: "the place where the bread is well baked." Rashi prefers the first explanation. See Rashi's comments to tractate Sanhedrin 102b.

34. Rashi: "You would have lifted up the hems of your robe from between your legs in order to run faster."

35. Manasseh's comments, revealed to Rav Ashi in a dream and not discussed elsewhere in the Talmud, entered the heart of the halakhic world as practical instructions for all time in the Shulchan Arukh, Orah Hıaim, section 167:1, under the section headings "Hilkhot Bitziat Ha-Pat" [The laws of breaking bread], "Seudah" [The meal], and "Birkat Ha-Mazon" [Grace after meals]. 